\title{
COVID-19 and Stock Market Liquidity: An Analysis of Emerging and Developed Markets
}

\author{
Godfrey Marozva*'D, Margaret Rutendo Magwedere**
}

\begin{abstract}
Using a panel of indices for five developed market and five emerging markets for the period from 31 December 2019 to 19 June 2020, the relationship between stock market liquidity and COVID-19 pandemic is examined. The study is the first to interrogate nexus using three measures of liquidity, the percentage spread, market depth and Amihud's (2002) ILLIQ measure. The pandemic is a global health condition with financial market implications, the results indicate that, stock market liquidity improved as we found a negative and significant relationship between illiquidity and COVID-19 across all the liquidity measures in all markets. However, improvements in stock market liquidity were more prevalent in developed markets relative to emerging markets. The results show that volatility negatively affected liquidity when illiquidity was measured by spread. Future research should focus on the impact of quantitative easing on stock markets liquidity during market turmoil.
\end{abstract}

Keywords: COVID-19; liquidity; illiquidity; volatility; stock returns.

JEL classification: G120; G150; G010.

\section{INTRODUCTION}

Pandemics can trigger unprecedented changes in the financial markets which in turn affects the liquidity of stocks. Public health pandemics are becoming invisible risks that alter firm value with the onset of a pandemic. Panic and uncertainty in the financial market caused by public health diseases such as COVID-19 impacts volatility of stock markets (see Pastor and Veronesi, 2012). According to Glosten and Milgrom (1985) and Hasbrouck (1988) bidask spreads increases in the presence of risk and uncertainty leading to the corrosion of financial market liquidity. With the onset of COVID-19, the implementations of restrictions and lockdowns further contribute to the deterioration of the liquidity and stability of markets

\footnotetext{
* Department of Finance, Risk Management and Banking, Faculty of Economics and Financial Sciences, University of South Africa, South Africa; e-mail:marozg@unisa.ac.za.

Department of Finance, Risk Management and Banking, Faculty of Economics and Financial Sciences, University of South Africa, South Africa; e-mail: rumagwedere@gmail.com (corresponding author).
} 
(Baig et al., 2021). Ironically, news associated with infectious diseases can cause panic and impact investors' sentiments which can be translated to financial markets (Ederington and Lee, 1996; Tetlock, 2007).

Market liquidity tends to significantly deteriorate in crisis periods as a result of difficulties in executing trades, drop in market depth, and increased volatility among others (Capponi et al., 2019). During crisis liquidity deteriorates as banks de-risk by selectively deleveraging and unwinding large non-performing loans resulting in reduced liquidity (Reinhart and Rogoff, 2009). Liquidity situations can vary significantly across different countries during normal and crises time. Crisis period can trigger flight to safety or flight to quality with significant effect on portfolio flows. Under the COVID-19 the emerging and frontier markets experienced significant portfolio reversals (International Monetary Fund, 2020a). It is the aim of this article to examine the differences in stock liquidity between markets during the COVID-19 period. Increased uncertainty in the markets due to the pandemic has tightened financial conditions as shown in Figure no. 1. As global investors' sentiments factored in the risks of COVID-19 the markets experienced a surge in implied volatility (International Monetary Fund, 2020a).

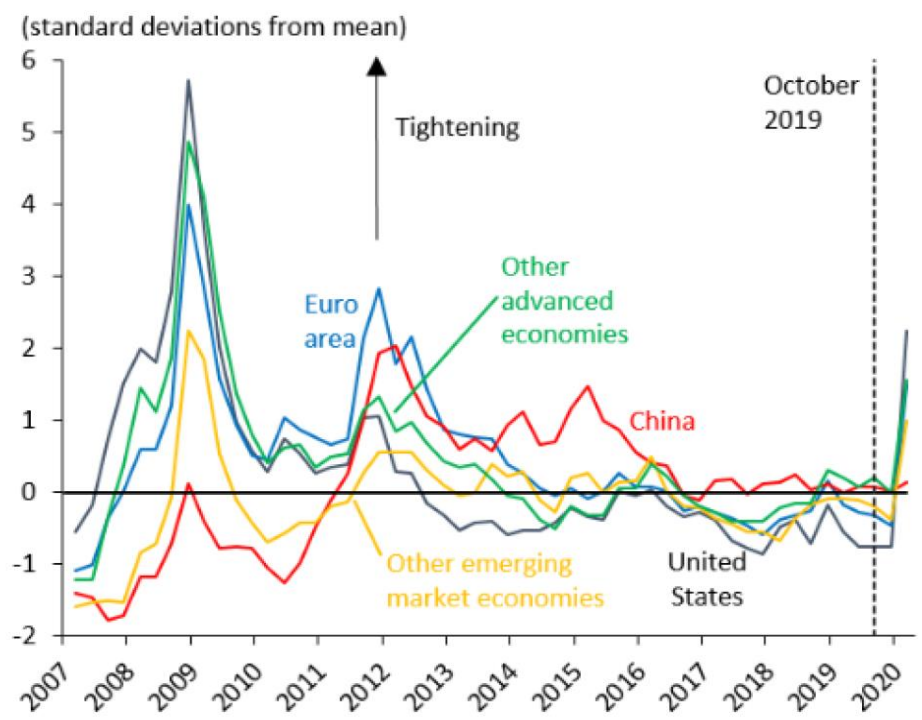

Note: "Other advanced economies" comprises of Australia, Canada, Denmark Hong Kong SAR, Japan, Korea Norway, Singapore, Sweden, Switzerland and the United Kingdom. "Other emerging market economies" comprises Brazil, India, Mexico, Poland, Russia and Turkey

Source: International Monetary Fund (2020a)

Figure no. 1 - Tightening of financial conditions

Market conditions respond to major events such as disasters, political events and diseases. As in Figure no. 1 the financial conditions of different economies tightens as a response to the onset of the COVID-19 pandemic. According to the International Monetary Fund (2020b) demand for goods and services has been affected by income loss, fear of contagion, and heightened uncertainty as people are spending less. Due to the measures to 
contain COVID-19 global activity is very low which has pushed prices down due to amplified international trade and financial linkages. As a result of tightening financial conditions globally central banks are expected to intervene with measures to ensure financial stability.

Major macro-economic interventions were witnessed in several countries in response to COVID-19. In the USA the central bank implemented measures such as policy rate cuts, central bank liquidity support and the central bank purchase schemes among others. To limit the economic damage from the pandemic the USA Federal Reserve (Fed) stepped in with an extensive array of actions, including up to $\$ 2.3$ trillion in lending to support local governments and small and medium-sized businesses (Cheng et al., 2020). The Fed intends to buy at least $\$ 500$ billion in Treasury securities and \$200 billion in government-guaranteed mortgagebacked securities. A total of $\$ 600$ billion worth of four-year loans were also promised to be funded by the Fed. In addition, a fiscal response of at least $\$ 2$ trillion support for businesses and checks to every household was rolled out. The Treasury also pledged $\$ 50$ billion from its Exchange Stabilization Fund to protect the Fed from losses (Cheng et al., 2020). Furthermore, the Coronavirus Aid, Relief, and Economic Security (CARES) Act was signed into law and provided \$2.2 trillion as economic support to the American people from the public health and economic impacts of COVID-19. New and expanded programs were introduced by the Fed with an additional $\$ 454$ billion that could be used to bankroll the Fed's programs and the new and the $\$ 185$ billion expanded programs that were announced on April 9.

On the contrary, most of the Eurozone countries did not implement policy rate cuts as a response measure to COVID-19. However, liquidity support and the central bank purchase schemes were among the responsive policy measures adopted in the Eurozone. European Central Bank (ECB) increased size of its Pandemic Emergency Purchase Programme (PEPP) to 1.35 trillion euros ( $\$ 1.52$ trillion) leaving benchmark Deposit Facility Rate at $-0.5 \%$ (Reuters, 2020). United Kingdom also adopted similar measures with the policy rate cuts, central bank purchase schemes and central bank liquidity support.

China implemented the policy rates cuts and the central bank liquidity support. In easing tightening financial conditions China injected gross liquidity of RMB 4.6 trillion into the banking system using the open market operations (reverse repos and medium-term lending facilities (International Monetary Fund, 2020a). On the other hand African countries face varying levels of risk of which diversified adapting response strategies to the COVID-19 have been adopted. Particularly, South Africa reduced the policy rate by a total 250 basis points during the lockdown period to have the policy rate at 3.75 percent. Furthermore, there are liquidity support measures in place such as temporary relief on bank capital requirements and reduced liquidity coverage ratio from 100 to 80 percent among others (International Monetary Fund, 2020a). In mitigating the external economic shocks some countries in the emerging markets such as Brazil, India and Russia had foreign exchange interventions a policy that was not used by developed countries. In addition to these highlighted policy responses both the developed and the emerging markets have varying financial policies for banks and borrowers respectively (International Monetary Fund, 2020a). These policies have been adopted to ensure economic and financial stability during the pandemic. Where interventions effective in curbing the crisis? It is the aim of this article to investigate the extent to which COVI-19 affected one of the most important fundamentals of financial markets, that is liquidity. The broad aim of the study is to examine the relationship between Covid-19 and liquidity. Therefore the study interrogated whether Covid-19 determine liquidity as measured by spread. Secondly, does Covid-19 determine liquidity as measured by depth? Lastly, does Covid-19 
determine liquidity as measured by Amihud (2002)'s illiquidity? An inflection point was signalled in the financial markets with the onset of the pandemic, however it was succeeded by some recovery posing questions on the relationship between the pandemic and liquidity.

\section{LITERATURE REVIEW}

Using the theories of demand and supply to frame our study the pandemic adversely impact on cash-flows and the tightening of global liquidity demands. Furthermore, heterogeneity in how firms access cash and credit can influence the performance of firms (Kahle and Stulz, 2013; Pinkowitz et al., 2016; Giroud and Mueller, 2017). Firms with extra liquidity, less leverage, and better access to credit (e.g., more profitable firms) experience less severe stock value declines than otherwise identical firms (Ding et al., 2020). Due to globalisation, firms are connected through networks of suppliers and customers such that some firms' networks of suppliers and customers are situated in countries more affected by the pandemic than others (e.g. Long and Plosser, 1983; Acemoglu et al., 2012; Acemoglu et al., 2017). More-affected firms are likely to experience greater disruptions to production and sales and hence larger stock price declines than similar firms with less COVID-19 exposure (Ding et al., 2020). Higher uncertainty causes firms to temporarily pause their investment and hiring generating sharp recessions and recoveries (Bloom, 2009).

During crises central bank lending and risk management policies are crucial for preserving economic stability and managing systemic crises (Cecchetti and Disyatat, 2010). The central banks' lender-of-last-resort (LOLR) function is vital under crisis as they provide public liquidity. Under COVID-19 the compulsory measures necessary to contain the virus generated economic downturn with uncertainty around its length and severity. Faced with tightening financial conditions and in a bid to maintain the flow of credit to their respective economies central banks globally have adopted a number of approaches such as interest rate cuts, quantitative easing, increasing loan support to businesses and easing restrictions on the financial sector (International Monetary Fund, 2020a). As the numbers of infections surges the global central banks have become the first line of defense for the economy particularly the financial markets. Central banks in both developed and emerging markets responded to the COVID-19 pandemic by instituting several measures to ensure economic and financial stability.

Due to health crisis of COVID-19 and the measures taken to contain its spread, volatility in the markets spiked triggering deterioration in market liquidity. Recent studies found negative stock reactions, increased systematic risk and increased market volatility in response to COVID-19 (Al-Awadhi et al., 2020; Zhang et al., 2020; Baig et al., 2021). However, none of these studies compared the impact of the pandemic to stock market liquidity in developed and emerging market. The World Health Organisation (WHO) predicted the worst of the pandemic in developing countries especially in Africa due to inadequate infrastructure in the public health facilities (World Health Organisation, 2020). Global economies possibly face a public health crisis and a looming financial crisis at the same time. Across the globe, different stock market bourses have responded differently to the pandemic and to the policy responses by governments. The International Monetary Fund (2020a) opined that just as the pandemic is severely affecting people with pre-existing conditions, markets with pre-existing financial vulnerabilities will be the worst affected. The present market conditions provide the basis to examine the effects of COVID-19 on stock liquidity of emerging markets and developed markets during the times of policy uncertainty in both markets. Furthermore, COVID-19 can 
be tracked with precision on when different countries were affected by the pandemic. The trajectory of the pandemic is likely to vary across the world with varying impact on the stock liquidity of developed and emerging markets.

\section{DATA AND RESEARCH METHODOLOGY}

\subsection{Data source, sample selection and variables}

The equity market indices of developed and emerging markets are used to explore the relationship between equity liquidity and COVID-19. For the empirical investigation, the selected stock indices were those that closely tracked the performance of the overall market. A total of 10 indices were examined, these were equally distributed between well developed markets and developing markets. Developed markets/ Indices included: United States of America/ S \& P 500; Hong Kong/ Hang Seng; Japan/ Nikkei 225; Germany/ Dax and Canada/ TSX. While the selected emerging markets were South Africa/ JSE; China/ Shangai; Mexico/IPC; South Korea/ KOSPI and Brazil/IBOVESPA. The analysis was done on these two forms of markets because they are technically and fundamentally different (Marozva, 2020). The study by Bekaert and Harvey (2017) indicate that emerging markets are mechanically and dynamically unique as they are not entirely integrated into world capital markets yet and therefore must be treated as a distinct asset class. Earlier, Kang and Zhang (2014) argued that liquidity in emerging stock markets is different from developed stock markets.

We employ intraday data on the selected indices. The period under examination is the post COVID-19 first case period, which runs from December 31, 2019 to June 19, 2008 (i.e., a period which witnessed a significant spread and rise of Coronavirus cases across the world). Only days with trading volume data are included in the research samples under consideration. In line with Chiu et al. (2012) quotes that met all of the following four conditions were included: (a) the bid or the ask price is greater than zero, (b) the bid or the ask spread is greater than zero, (c) the price or volume is greater than zero, and (d) all quotes with a positive bidask spread. Unlike Chiu et al. (2012) the trades were not screened based on stock return, the changes in ask quotes nor the changes in bid quotes. Three liquidity measures are examined, the percentage spread, Amihud (2002)'s ILLIQ measure and market depth.

The percentage spread as the measure of illiquidity was calculated as $\left[\frac{A s k_{t}-B^{-1 d_{t}}}{\left(A s k_{t}+B i d_{t}\right) / 2}\right] \times$ 100 where $A s k_{t}\left(B_{i d}\right)$ is the intraday ask (bid) price at time t (see Berkman and Nguyen, 2010; Chiu et al., 2012). The higher the bid-ask spread the higher the percentage spread, meaning the lower the liquidity vice versa.

The Amihud (2002)'s illiquidity measure (ILLIQ) is defined as the average ratio of the daily absolute return to the dollar trading volume on that day. Unlike other illiquidity (such as, bid-ask spread, quoted or effective spread), this measure does not require a lot of intraday microstructure data, which are unavailable for many stocks. In their argument for ILLIQ measure Lou and Shu (2017) indicate that this measure is simple to compute. They also assert that ILLIQ measure can be calculated for days when there is no price change, which is of particular concern in emerging markets. ILLIQ measure is calculated as $I L L I Q_{i, t}=$ $\frac{1}{D_{i, t}} \sum_{t=1}^{D_{i, t}} \frac{\left|R_{i, d}\right|}{D V l_{i, d}}$ where ILLIQ $\mathrm{i}_{\mathrm{i}, \mathrm{t}}$ is the Amihud (2002)'s illiquidity measure of firm i estimated in month $\mathrm{t} ;\left|R_{i, d}\right|$ and $D V o l_{i, d}$ are daily return and daily dollar trading volume for stock i on 
day d; $D_{i, t}$ is the of days for which data is available for stock $i$ in month $t$. All other things constant, higher trading volume results in lower Amihud's ILLIQ measure. This implies that the higher the trading volume the higher the stock liquidity and vice versa.

According to Chiu et al. (2012) the market depth is computed as the number of shares at the best bid and ask price multiplied by their respective prices and then take the average of each depth divided by 100 to reduce the size of the variable. Brockman and Chung (1999) assert that dollar depth measure of liquidity is more relevant. This was later confirmed by Marozva and Makina (2020) who argues that market liquidity is multidimensional thus, equity liquidity has both a price dimension (spread) and a quantity dimension (depth).

In line with Al-Awadhi et al. (2020) the number of active cases and death from COVID19 was used as the proxy for the Coronavirus crises/ epidemic. Data for the number of daily active confirmed cases and daily cases of death from COVID-19 for the countries under analysis were obtained from Worldometer, these were available on daily basis.

\subsection{Model specification}

A multiple regression analysis was carried out to examine the nexus between stock liquidity and COVID-19. Initially, the effects of COVID-19 on percentage spread was tested using equation 1 . To control for the factors that are imperative in determining the percentage spread, the article followed Chiu et al. (2012) and Stoll (2000) to explore the following regression model:

$$
\text { Spread }_{i, t}=\alpha+\beta_{1} \text { Spread }_{i, t-1}+\beta_{2} R_{i, t}+\beta_{3} \text { Vol }_{i, t}+\beta_{4} \operatorname{LogV}_{i, t}+\beta_{5} \text { COVID_19 }_{i, t}+\varepsilon_{i . t}
$$

where COVID-19 $9_{\mathrm{i}, \mathrm{t}}$ is either (1) daily growth rate of the total confirmed cases of COVID-19 in country $i$ at time $t$ or (2) daily growth rate of total cases of death caused by COVID-19 on country $\mathrm{i}$ at time $\mathrm{t} ; \operatorname{Spread}_{i, t}$ is the daily percentage spread for index $\mathrm{i}$ at time $\mathrm{t} ; R_{i, t}$ is the daily return for index $\mathrm{i}$ at time $\mathrm{t} ; \operatorname{Vol}_{i, t}$ is the daily volatility for index $\mathrm{i}$ at time $\mathrm{t} ; \log V_{i, t}$ is the logged daily trading volume for index $\mathrm{i}$ at time $\mathrm{t}$; Spread $_{i, t-1}$ is the daily percentage spread for index $\mathrm{i}$ on day $t-1$; and $\varepsilon_{i . t}$ is the error term for index $\mathrm{i}$ at time $\mathrm{t}$.

The second model involved testing the effects of COVID-19 on Amihud (2002)'s illiquidity measure (ILLIQ) and the model was specified in equation 2 as follows:

$$
I L L I Q_{i, t}=\alpha+\beta_{1} I_{L L I Q} Q_{i, t-1}+\beta_{2} \text { Vol }_{i, t}+\beta_{3} \text { Spread }_{i, t}+\beta_{4} \text { COVID_19 }_{i, t}+\varepsilon_{i, t}
$$

where ILLIQ $Q_{i, t}$ is Amihud (2002)'s illiquidity measure for index $\mathrm{i}$ at time $\mathrm{t}$; and Where $I_{L L I Q} Q_{i, t-1}$ is Amihud (2002)'s illiquidity measure for index $\mathrm{i}$ at time $\mathrm{t}-1$.

Following Ahn et al. (2001) to control for the factors that are crucial in determining market depth when investigating the relationship between market depth and COVID-19, the following regression model was specified:

$$
\text { Depth }_{i, t}=\alpha+\beta_{1} \text { Depth }_{i, t-1}+\beta_{2} \text { Ntrade }_{i, t}+\beta_{3} \text { Vol }_{i, t}+\beta_{4} \text { COVID_19 } 9_{i, t}+\varepsilon_{i . t}
$$

where Depth $_{i, t}$ is the daily average of the market depth for index i at time $\mathrm{t}$; eepth $_{i, t-1}$ is the daily average of the market depth for index i on time t- 1 ; and $N$ trade $_{i, t}$ is the daily number of trades for index $i$ on time t. 


\section{EMPIRICAL RESULTS}

\subsection{Descriptive statistics}

Table no. 1 provides the descriptive statistics of the study sample including the developed markets and emerging markets respectively.

Table no. 1 - Descriptive statistics

\begin{tabular}{lrrrrrrr}
\hline \multicolumn{7}{c}{ Developed Markets } \\
\hline Variables & \multicolumn{1}{c}{ Mean } & \multicolumn{1}{c}{ Median } & Maximum & Minimum & Std. Dev. & Jarque-Bera Obs. \\
\hline CCPOP & 0.07 & 0.01 & 0.66 & 0.00 & 0.13 & $1,123.80$ & 581 \\
CDPOP & 0.00 & 0.00 & 0.04 & 0.00 & 0.01 & $1,016.01$ & 581 \\
CUMC & $142,639.80$ & $1,044.00$ & $2,163,290.00$ & 0.00 & $405,539.60$ & $4,265.10$ & 581 \\
CUMD & $7,797.37$ & 4.00 & $117,717.00$ & 0.00 & $23,343.45$ & $4,247.93$ & 581 \\
ILLIQ & 0.00 & 0.00 & 0.01 & 0.00 & 0.00 & $3,795.16$ & 581 \\
RETURN & -0.04 & 0.12 & 11.96 & -12.34 & 2.55 & 734.13 & 581 \\
SPREAD & 1.99 & 1.41 & 9.67 & 0.00 & 1.70 & 840.38 & 581 \\
VOLATILITY & $1,210.50$ & 874.53 & $7,988.27$ & 15.07 & $1,190.64$ & $1,026.24$ & 581 \\
VOLUME '000 & $1,610,000.00$ & $305,000.00$ & $9,040,000.00$ & 0.00 & $2,230,000.00$ & 230.36 & 581 \\
\hline \multicolumn{7}{c}{ Emerging Markets } \\
CCPOP & 0.0227 & 0.0054 & 0.4527 & 0.00 & 0.0581 & $16,845.93$ & 575 \\
CDPOP & 0.0013 & 0.0001 & 0.0220 & 0.00 & 0.0035 & $5,881.23$ & 575 \\
CUMC & 46,781 & 7,572 & 955,377 & 0.00 & 119,050 & 21,54 & 575 \\
CUMD & 2,662 & 131 & 46,510 & 0.00 & 6,680 & 9,798 & 575 \\
ILLIQ & 0.0001 & 0.0000 & 0.0036 & 0.00 & 0.0002 & $126,501.10$ & 575 \\
RETURN & 0.0332 & 0.0489 & 13.9082 & -14.78 & 2.5209 & $1,340.27$ & 575 \\
SPREAD & 2.1357 & 1.7474 & 21.6354 & -163.18 & 7.2761 & $5,159,694$ & 575 \\
VOLATILITY & $2,822.37$ & 195.06 & $59,670.99$ & 5.66 & $6,266.38$ & $20,528.08$ & 575 \\
VOLUME '000 & 119,000 & 10,117 & $1,320,000$ & 0.00 & 177,000 & 1,415 & 575 \\
\hline
\end{tabular}

Note: CCPOP is cumulative cases per population, CDPOP cumulative deaths per population, CUMC cumulative cases, CUMD cumulative deaths, ILLIQ is illiquidity, ${ }^{*} \mathrm{p}<0.05, * * \mathrm{p}<0.01, \mathrm{p}<0.001$

Source: Authors' own calculations using Stata 15.1

Comparing the volumes traded between the developed and the emerging markets, the developed markets had more volumes traded with a maximum of 9.04 billion for the period under study as compared to a maximum of 1.320 billion in emerging markets. The average trading volume was 1,610,000,000.00 for developed markets whilst the emerging market had an average trading volume of $119,000,000.00$. Zhu (2014) argues that volatility is a key driver among investors for market selection as share prices decreases with increase in volatility. Despite the higher number of traded volumes on the stock market the developed economies have a higher number of cumulative cases and deaths with a maximum of 2,163,290.00 and $117,717.00$ respectively. On the contrary in emerging markets the cumulative cases and death had a maximum of 955,377 and 46,510 respectively. For the period under study the developed economies had more active cases and deaths than in the emerging markets. The data showed an average of cumulative deaths for the developed and emerging markets of 7,797.37 and 2,662 respectively. On the other hand, volatility of the two markets had a standard deviation of 6,266.38 for the emerging markets against a standard deviation of 1,026.24 for the developed markets. The economic crises induced by COVID-19 amplified concerns by investors resulting 
in stock market fluctuations due to panic sales and the flight to safety by investors possibly resulting in more fluctuation in the emerging markets than the developed markets (International Monetary Fund, 2020b). The pandemic increased the volatility in the markets with a higher standard deviation of 6,266.38 for emerging markets whilst the volatility standard deviation of $1,190.64$ for the developed economies. Average illiquidity was 0.00 in the developed markets and 0.0001 for the emerging markets. The spread in the emerging markets had a maximum of 21.6354 and a minimum of -163.18 was wider than the spread in the developed markets for the period under study. The spread in developed markets had a maximum and a minimum of 9.67 and 0.00 respectively. Therefore, the descriptive statistics in Table no. 1 shows that the severity of the pandemic on spread was higher in the emerging markets than in the developed markets. The spread of the virus for the period under study is an exogenous incident that possibly has no comprehension of modern market structures nor directly responds to them. Cross correlation of the variables in this study are discussed in section 4.2 .

\subsection{Cross-correlation analysis}

Table no. 2 presents the cross-correlation matrix of the study sample including the developed markets and emerging markets respectively

Table no. 2 - Cross correlation matrix

\begin{tabular}{|c|c|c|c|c|c|c|c|c|c|}
\hline \multicolumn{10}{|c|}{ Developed markets cross-correlation matrix } \\
\hline Variables & 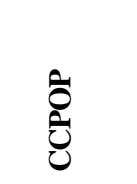 & $\begin{array}{l}\hat{0} \\
\hat{े}\end{array}$ & $\sum^{U}$ & 罗 & $\stackrel{9}{\stackrel{9}{3}}$ & 売 & $\frac{2}{\sqrt{n}}$ & 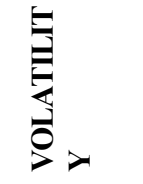 & $\frac{\sum^{5}}{\sum_{0}^{\prime}}$ \\
\hline$\overline{\mathrm{CCPOP}}$ & 1.0000 & & & & & & & & \\
\hline CDPOP & $0.9794 * * *$ & 1.0000 & & & & & & & \\
\hline CUMC & $0.895 * * *$ & $0.8636^{* * *}$ & 1.0000 & & & & & & \\
\hline CUMD & $0.8916^{* * *}$ & $0.8709^{* * *}$ & $0.9971 * * *$ & 1.0000 & & & & & \\
\hline ILLIQ & $-0.1882 * * *$ & $-0.1730^{* * * *}$ & $-0.1256^{* * * *}$ & $-0.1209 * * *$ & 1.0000 & & & & \\
\hline RETURN & $0.0762 *$ & 0.0614 & 0.0487 & 0.0428 & 0.0345 & 1.0000 & & & \\
\hline SPREAD & -0.0536 & $-0.0808 *$ & -0.0382 & -0.0497 & $0.0817 * *$ & $-0.1228 * * *$ & 1.0000 & & \\
\hline VOLATILITY & $-0.2535 * * *$ & $-0.2551 * * *$ & $-0.2509 * * *$ & $-0.2472 * * *$ & $0.3326^{* * * *}$ & $-0.1153 * * *$ & $0.5136 * * *$ & 1.0000 & \\
\hline VOLUME & $0.3435^{* * * *}$ & $0.3288^{* * * *}$ & $0.5169^{* * *}$ & $0.5058^{* * * *}$ & $-0.2702 * * *$ & -0.0179 & $.1892 * * *$ & $-0.2280 * * * 1$ & 1.0000 \\
\hline \multicolumn{10}{|c|}{ Emerging markets cross-correlation matrix } \\
\hline CCPOP & 1.0000 & & & & & & & & \\
\hline CDPOP & $0.9366^{* * * *}$ & 1.0000 & & & & & & & \\
\hline CUMC & $0.9455^{* * *}$ & $0.885 * * *$ & 1.0000 & & & & & & \\
\hline CUMD & $0.9411 * * *$ & $0.9567 * * *$ & $0.9720^{* * * *}$ & 1.0000 & & & & & \\
\hline ILLIQ & $-0.1084 * * *$ & $-0.1320 * * *$ & -0.0122 & -0.0545 & 1.0000 & & & & \\
\hline RETURN & $0.0725^{*}$ & 0.0669 & 0.0668 & 0.0683 & $-0.0789^{*}$ & 1.0000 & & & \\
\hline SPREAD & 0.0095 & 0.0130 & 0.0089 & 0.0108 & -0.0068 & $-0.1071^{* *}$ & 1.0000 & & \\
\hline VOLATILITY & $0.1352 * * *$ & $0.1565^{* * * *}$ & $0.1314 * * *$ & $0.1493^{* * * *}$ & $-0.1343^{* * * *}$ & $-0.1051^{* *}$ & $0.2214 * * * *$ & 1.0000 & \\
\hline VOLUME & -0.0386 & -0.0490 & $-0.1644 * * *$ & $-0.1468 * * *$ & $-0.3061^{* * * *}$ & -0.0154 & $0.0713 * * * *$ & $-0.1606^{* * *} 1$ & 1.0000 \\
\hline
\end{tabular}


The great uncertainty of the pandemic and its associated economic losses due to the policy responses to contain the virus resulted in highly volatile and unpredictable financial markets (Zhang et al., 2020). From Table no. 2 the cross correlations show that the volatility in emerging markets increased with an increase in all the measurements of COVID-19 (i.e. cumulative cases per population, cumulative deaths per population, cumulative cases and cumulative deaths). This is contrary to the developed markets where there was an inverse relationship between volatility and cumulative cases per population, cumulative deaths per population, cumulative cases and cumulative deaths. In the developed markets an increase in cumulative cases per population, cumulative deaths per population, cumulative cases and cumulative deaths reduced volatility. The uncertainty and unpredictability of the trajectory of the pandemic resulted in greater portfolio outflows in the emerging markets (International Monetary Fund, 2020b). The relationship between the stock market return and volatility was negative in both markets. An increase in volatility is associated with a decrease in stock market return in both developed and emerging markets or a decrease in volatility is associated with an increase in stock market return. Increase in cumulative cases per population, cumulative cases and cumulative deaths are associated with an increase in spread for both the developed and emerging markets. Therefore, there is a positive relationship between cumulative cases per population, cumulative cases, cumulative deaths and spread in both the developed and emerging markets. However, cumulative deaths per population showed a reduction in spread as the number of cumulative deaths per population increased. An increase in, cumulative cases and cumulative deaths is associated with decrease in illiquidity in both markets. However, for the emerging markets there is positive correlation between cumulative cases per population and cumulative deaths per population. An increase in cumulative cases per population and cumulative deaths per population is associated with an increase in illiquidity in the emerging markets. It is observed from these results that illiquidity is positively correlated with spread in developed markets whilst in emerging markets these variables are negatively correlated. An increase in illiquidity in the developed markets is associated with an increase in the spread. Ibikunle and Rzayev (2020) observed that liquidity improves as spreads narrows during the volatile trading induced by COVID-19.

Developed markets in this study, have a positive relationship between the volume traded and cumulative cases per population, cumulative deaths per population, cumulative cases and cumulative deaths. An increase in the cumulative cases per population, cumulative deaths per population, cumulative cases and cumulative deaths is associated with an increase in the volume traded. On the contrary in the emerging markets, cumulative cases and cumulative deaths had an inverse relationship with volume traded. An increase in cumulative cases and cumulative deaths is associated with a decrease in the volume traded. However, when cumulative cases and cumulative deaths measures were used the there is a negative relationship with the volume traded in the emerging markets. An increase in cumulative cases and cumulative deaths is associated with a decrease in the volume traded. There is a negative correlation between illiquidity and the volume traded in both markets. An increase in illiquidity is associated with a decrease in the volume traded. Section 4 discusses the empirical results of the study.

\section{EMPIRICAL RESULTS}

A panel data analysis was carried out. The models were first tested for cross sectional dependence and the null hypothesis could not be rejected under all models. Hausman test was 
used to choose the most efficient model and the Hausman test results are presented at the bottom of the estimation output tables corresponding to each model (results on unit roots are not included for space consideration but they are available on request). The results models were run with firm fixed-effects and random-effects with cluster robust using STATA software. The following table presents the first set of results on the effects of COVID-19 on liquidity as measured by spread where the fixed effects model was selected as the most appropriate.

Table no. 3 - Panel data regression output for the effects of COVID-19 on the spread

\begin{tabular}{|c|c|c|c|c|}
\hline & $\begin{array}{l}\text { Fixed Effects } \\
\text { Spread_Dev } \\
\text { (1) }\end{array}$ & $\begin{array}{c}\text { Fixed Effects } \\
\text { Spread_Emerg } \\
(\mathbf{2})\end{array}$ & $\begin{array}{c}\text { Fixed Effects } \\
\text { Spread_Dev } \\
\text { (3) }\end{array}$ & $\begin{array}{c}\text { Fixed Effects } \\
\text { Spread_Emerg } \\
(\mathbf{4})\end{array}$ \\
\hline L.Spread & $\begin{array}{r}0.489^{* *} \\
(0.0795)\end{array}$ & $\begin{array}{r}0.0219 \\
(0.0108)\end{array}$ & $\begin{array}{r}0.487^{* * *} \\
(0.0812)\end{array}$ & $\begin{array}{r}0.0223 \\
(0.0112)\end{array}$ \\
\hline $\mathbf{R}$ & $\begin{array}{r}-0.0525 \\
(0.0243)\end{array}$ & $\begin{array}{l}-0.160^{* * *} \\
(0.0320)\end{array}$ & $\begin{array}{r}-0.0529 \\
(0.0243)\end{array}$ & $\begin{array}{l}-0.161^{\text {*** }} \\
(0.0309)\end{array}$ \\
\hline Vol & $\begin{array}{r}0.000378^{*} \\
(0.000110)\end{array}$ & $\begin{array}{r}0.000260^{* * * *} \\
(0.0000164)\end{array}$ & $\begin{array}{r}0.000377^{*} \\
(0.000109)\end{array}$ & $\begin{array}{l}0.000262^{* * * *} \\
(0.0000177)\end{array}$ \\
\hline $\log V$ & $\begin{array}{l}3.325^{* * *} \\
(0.616)\end{array}$ & $\begin{array}{r}5.276^{*} \\
(1.155)\end{array}$ & $\begin{array}{l}3.334^{* *} \\
(0.618)\end{array}$ & $\begin{array}{r}5.155^{*} \\
(1.160)\end{array}$ \\
\hline COVID_19CP & $\begin{array}{r}-1.231^{* * *} \\
(0.129)\end{array}$ & $\begin{array}{l}-5.050^{*} \\
(1.353)\end{array}$ & & \\
\hline COVID_19DP & & & $\begin{array}{r}-20.61^{* *} \\
(3.129)\end{array}$ & $\begin{array}{r}-77.33 \\
(33.54)\end{array}$ \\
\hline _cons & $\begin{array}{r}-26.43^{* * *} \\
(4.934)\end{array}$ & $\begin{array}{l}-35.40^{*} \\
(8.082)\end{array}$ & $\begin{array}{r}-26.50^{* *} \\
(4.934)\end{array}$ & $\begin{array}{l}-34.56^{*} \\
(8.099)\end{array}$ \\
\hline$N$ & 450 & 442 & 450 & 442 \\
\hline$R^{2}$ & 0.775 & 0.596 & 0.775 & 0.594 \\
\hline Hausman Chi-Square & $145.58^{* * * *}$ & $104.57^{* * *}$ & $226.6^{* * * *}$ & $83.73^{* * * *}$ \\
\hline
\end{tabular}

Table no. 3 reports the coefficients of the panel regressions results for the effects of COVID-19 on stock liquidity as measured by percentage spread over the period 31 December 2019 to 19 June 2020. Panel 1 and Panel 2 report the coefficients of the panel regressions for the ratio of total confirmed cases of COVID-19 to population (COVID-19CP) amongst other control variables for developed and emerging markets in that order. Panel 3 and Panel 4 report the coefficients of the panel regressions for total confirmed deaths from COVID-19 as a ratio of total population (COVID-19DP) amongst other control variables for developed and emerging markets respectively.

Results revealed that spread was negatively affected by cumulative number of confirmed cases and the total number on deaths of COVID-19. The relationship was significant for both emerging and developed markets for cumulative cases of Coronavirus, though more significant 
for the later market. It was not the case with the cumulative deaths as the relationship was only significant under developed markets. This implies that markets became more liquid with the increase in number of cases and deaths contrary to what is expected during crises. If markets are stable it is expected that bid-ask spreads become narrower and hence lower transaction costs. During stability in financial markets, there are many buyers and many sellers, meaning that any order imbalance can be matched resulting in a small movement in the price of the asset being traded. This is completely opposite to what is expected during crises, where markets exhibit a wider bid ask spread (Diamond and Rajan, 2001).

The results in Table no. 3 further highlighted that developed markets liquidity significantly improved relative to emerging markets as expected. This is attributed to substantial liquidity injections that developed countries implemented through several quantitative easing programmes. The COVID-19 positively affected stock market liquidity in developed markets even though they were savagely affected by Coronavirus relative to emerging markets by all measurement matrices. Other results indicate that spread is positively related to volatility, meaning the higher the volatility the less liquid are the indices across markets. Returns had negative and significant influence on stock illiquidity. The higher the return the higher the liquidity as measured by spread which is contrary to most empirical findings (see for example Amihud and Mendelson, 1986; Chiu et al., 2012).

Table no. 4 - Panel data regression output for the effects of COVID-19 on the depth

\begin{tabular}{|c|c|c|c|c|}
\hline & $\begin{array}{c}\text { Fixed Effects } \\
\text { Depth_Dev } \\
\text { (5) }\end{array}$ & $\begin{array}{c}\text { Fixed effects } \\
\text { Depth_Emerg } \\
\text { (6) }\end{array}$ & $\begin{array}{c}\text { Random Effects } \\
\text { Depth_Deveping } \\
\text { (7) }\end{array}$ & $\begin{array}{c}\text { Random_Effects } \\
\text { Depth_Emerg } \\
\text { (8) }\end{array}$ \\
\hline L.Depth & $\begin{array}{r}-0.0256 \\
(0.0160)\end{array}$ & $\begin{array}{r}-0.000570 \\
(0.0274)\end{array}$ & $\begin{array}{c}0.860^{* * *} \\
(0.0505)\end{array}$ & $\begin{array}{r}0.945^{* * *} \\
(0.0397)\end{array}$ \\
\hline $\mathbf{R}$ & $\begin{array}{r}0.000169 \\
(0.000188)\end{array}$ & $\begin{array}{r}0.000862^{*} \\
(0.000271)\end{array}$ & $\begin{array}{l}-0.00418^{*} \\
(0.00203)\end{array}$ & $\begin{array}{r}-0.00130 \\
(0.00148)\end{array}$ \\
\hline Vol & $\begin{array}{r}0.00000377 \\
(0.00000173)\end{array}$ & $\begin{array}{r}-0.000000763 \\
(0.000000589)\end{array}$ & $\begin{array}{c}0.0000153^{* * * *} \\
(0.00000417)\end{array}$ & $\begin{array}{r}0.00000387 \\
(0.00000247)\end{array}$ \\
\hline Ntrade & $\begin{array}{l}0.808^{* * *} \\
(0.0236)\end{array}$ & $\begin{array}{l}0.791^{* * * *} \\
(0.0557)\end{array}$ & $\begin{array}{r}0.129^{*} \\
(0.0511)\end{array}$ & $\begin{array}{r}0.100 \\
(0.0647)\end{array}$ \\
\hline COVID_19CP & $\begin{array}{r}-0.00819 \\
(0.0340)\end{array}$ & $\begin{array}{r}0.0332 \\
(0.0629)\end{array}$ & & \\
\hline COVID_19DP & & & $\begin{array}{r}-1.053 \\
(0.900)\end{array}$ & $\begin{array}{r}2.393^{*} \\
(0.995)\end{array}$ \\
\hline _cons & $\begin{array}{r}5.066^{* * * *} \\
(0.109) \\
\end{array}$ & $\begin{array}{r}4.813^{* * * *} \\
(0.210) \\
\end{array}$ & $\begin{array}{l}0.611^{* * *} \\
(0.221) \\
\end{array}$ & $\begin{array}{r}0.107 \\
(0.0921) \\
\end{array}$ \\
\hline$N$ & 447 & 440 & 447 & 440 \\
\hline$R^{2}$ & 0.765 & 0.642 & 0.612 & 0.540 \\
\hline Hausman test statistic & $61679.07^{* * * *}$ & $1255.9^{* * *}$ & 1.587 & 2.4581 \\
\hline
\end{tabular}


Table no. 4 reports the coefficients of the panel regressions results for the effects of COVID-19 on stock liquidity as measured by depth over the period 31 December 2019 to 19 June 2020. Panel 5 and Panel 6 report the coefficients of the panel regressions for the ratio of total confirmed cases of COVID-19 to population (COVID-19CP) amongst other control variables for developed and emerging markets in that order. Panel 7 and Panel 8 report the coefficients of the panel regressions for total confirmed deaths from COVID-19 as a ratio of total population (COVID-19DP) amongst other control variables for developed and emerging markets respectively.

The results in Table no. 4 show that total deaths had statistically significant effects on market depth over the period of analysis. This indicated that the market depth representing the dollar value of trades increased with an increase in the number of deaths from COVID19. However, depth was not significantly affected by either total deaths or total case as a percentage of population for developed countries. Also, cumulative case of COVID-19 did not affect depth in emerging markets. In emerging markets, traders were not moved to trade by the number of cases but had to wait for confirmed death to act on the pandemic. The number of trades as expected was positively and significantly related to depth. Stock returns positively related to depth in emerging markets under Panel 6 and negatively related to developing markets depth under Panel 7.

Table no. 5 - Panel data regression output for the effects of COVID-19 on ILLIQ

\begin{tabular}{|c|c|c|c|c|}
\hline & $\begin{array}{c}\text { Fixed Effects } \\
\text { ILLIQ_Dev } \\
\text { (9) }\end{array}$ & $\begin{array}{c}\text { Fixed Effects } \\
\text { ILLIQ_Emerg } \\
(10)\end{array}$ & $\begin{array}{c}\text { Fixed Effects } \\
\text { ILLIQ_Dev } \\
\text { (11) }\end{array}$ & $\begin{array}{c}\text { Fixed Effects } \\
\text { ILLIQ_Emerg } \\
\text { (12) }\end{array}$ \\
\hline L.ILLIQ & $\begin{array}{r}0.131^{* * * *} \\
(0.109)\end{array}$ & $\begin{array}{r}0.0972^{* *} \\
(0.106)\end{array}$ & $\begin{array}{r}0.131^{* * * *} \\
(0.108)\end{array}$ & $\begin{array}{r}0.0973^{*} \\
(0.106)\end{array}$ \\
\hline Spread & $\begin{array}{r}-0.0000243 \\
(0.0000293)\end{array}$ & $\begin{array}{r}0.0000251 \\
(0.0000194)\end{array}$ & $\begin{array}{r}-0.0000240 \\
(0.0000291)\end{array}$ & $\begin{array}{r}0.0000251^{* * *} \\
(0.0000194)\end{array}$ \\
\hline Vol & $\begin{array}{l}0.000000169^{* * *} \\
(0.000000176)\end{array}$ & $\begin{array}{r}-6.26 \mathrm{e}-09^{* * * *} \\
(6.00 \mathrm{e}-09)\end{array}$ & $\begin{array}{r}0.000000169 \\
(0.000000176)\end{array}$ & $\begin{array}{r}-6.27 \mathrm{e}-09^{* * * *} \\
(6.01 \mathrm{e}-09)\end{array}$ \\
\hline COVID_19CP & $\begin{array}{r}0.0000206 \\
(0.0000458)\end{array}$ & $\begin{array}{r}0.0000355 \\
(0.0000393)\end{array}$ & & \\
\hline COVID_19DP & & & $\begin{array}{r}-0.000621^{* *} \\
(0.000954)\end{array}$ & $\begin{array}{r}0.000462 \\
(0.000560)\end{array}$ \\
\hline _cons & $\begin{array}{r}0.0000909^{*} \\
(0.000127) \\
\end{array}$ & $\begin{array}{r}0.0000461^{* * *} \\
(0.0000337) \\
\end{array}$ & $\begin{array}{r}0.0000896 \\
(0.000128) \\
\end{array}$ & $\begin{array}{r}0.0000463^{*} \\
(0.0000336) \\
\end{array}$ \\
\hline$N$ & 452 & 443 & 452 & 443 \\
\hline$R^{2}$ & 0.130 & 0.116 & 0.130 & 0.116 \\
\hline Hausman Chi-Square & $197.97^{* * * *}$ & $1209.0^{* * *}$ & $198.37^{* * *}$ & $1007.92^{* * *}$ \\
\hline
\end{tabular}

Table no. 5 reports the coefficients of the panel regressions results for the effects of COVID-19 on ILLQ over the period 31 December 2019 to 19 June 2020. Panel 9 and Panel 
10 report the coefficients of the panel regressions for the ratio of total confirmed cases of COVID-19 to population (COVID-19CP) amongst other control variables for developed and emerging markets in that order. Panel 11 and Panel 12 report the coefficients of the panel regressions for total confirmed deaths from COVID-19 as a ratio of total population (COVID19DP) amongst other control variables for developed and emerging markets respectively.

Panel 11 output shows that cumulative deaths negatively and significantly affected ILLIQ in developing countries during the period under consideration. This implies that as confirmed cumulative deaths increased the liquidity in developed stock markets deteriorated. The results confirm the results in Table no. 3 where liquidity improved with total deaths in developed markets. Contrary to Bai et al. (2018) who argue that markets become illiquid in times of crises. The difference could be that fact developed countries were better prepared for the COVID-19 than the 2007/2009 global financial crises. Other results show that volatility was negatively related to ILLIQ, implying that as volatility increased liquidity increased. The results were in line with Brunnermeier and Pedersen (2009) finding that volatility affects liquidity.

\section{CONCLUSIONS AND POLICY IMPLICATIONS}

Thus far, the determinants of liquidity have been studied widely. However, there is no study so far to the best of our knowledge that examines the effects of crisis on stock market liquidity. Specifically in this, the examination of the effects of a health crisis on stock market liquidity in both emerging and developed markets. Therefore, the aim of this article was to investigate the effects of COVID-19 on stock market liquidity in both emerging and developed markets.

Using a panel of five developed markets indices and five emerging markets indices from 31 December 2019 to 19 June 2020 and using fixed effects/ random effects as primary methods in the analysis, several deductions from the results were exposed. Firstly, there was a negative relationship between illiquidity as measured by spread and COVID-19, and the association is both statistically significant for developed countries under all cases of COVID19. The result was contrary to existing theory and other empirical studies and liquidity improved in times of crisis. The results were not as expected for emerging markets as confirmed cumulative number of COVID-19 deaths did not affect the spread. However, the cumulative cases resulted in the improvement in liquidity as measured by spread. The results indicate that countries both emerging and developing were proactive and better prepared for the pandemic than other crises. Alternatively the market interventions by respective governments to cushion their economies from the short term effects of pandemic could have prevented the adverse effects of the pandemic on liquidity.

Secondly, stock market depth was found to be significantly positively related to confirmed total deaths in emerging markets. Again, indicating that liquidity improved over the period of analysis as the cumulative number of deaths increased. These findings are contrary to theory and many empirical studies. This shows that liquidity is improved when countries are prepared. Though emerging markets did not inject much needed funding liquidity the markets were better prepared because they were affected much later save for China.

Thirdly, Amihud (2002)'s ILLIQ was found to be negatively related with cumulative number of confirmed COVID-19 deaths in developed markets. The results showed that liquidity improved with the increase in the number of COVID-19 cumulative deaths. 
Developed economies injected a significant amount of liquidity in the markets to quench the effects of COVID-19, this directly improved stock markets liquidity. The results showed that financial markets are better prepared for a pandemic than they are for financial crisis. Central banks and country finance ministries are recommended to pursue expansionary monetary and fiscal policies when faced with a health crisis.

Finally, volatility affected liquidity differently depending on how liquidity was measured. Volatility negatively affected liquidity when illiquidity was measured by spread and it was positively related to liquidity as measured by ILLIQ and market depth. The pandemic disrupted the supply chain, the working environment and the consumer demand in certain sectors of the economy. This can have implications of risk tolerance of market players with the implications that management should think of financial restructuring, and having dedicated teams skilled in driving liquidity initiatives and improvements in the working. The remote working that resulted from social distancing policies has the implication that management need to rethink the operating models of their businesses. The remote working as a result of social distancing requirement requires management to increase investment in financial technology to serve the customers' needs. Future research should focus on the impact of quantitative easing on stock markets liquidity during market turmoil. At the time of this study it was too early to understand the long term effects of the pandemic, further study is need on how the interventions by the central banks globally such as interest rates cuts have affected the financial sectors' interest margins. Furthermore there is need to examine the market liquidity during the pandemic for the period before the vaccines and during the rollout of vaccines. A comparative study on the state of affair of stock market liquidity before and during the crisis may provide important insights and significant contribution to the body of knowledge.

\section{ORCID}

Godfrey Marozva iD http://orcid.org/0000-0002-7028-4462

Margaret Rutendo Magwedere (iD http://orcid.org/0000-0001-7197-3924

\section{References}

Acemoglu, D., Carvalho, V. M., Ozdaglar, A., and Tahbaz-Salehi, A., 2012. The network origins of aggregate fluctuations. Econometrica, 80(5), 1977-2016. http://dx.doi.org/10.3982/ECTA9623

Acemoglu, D., Ozdaglar, A., and Tahbaz-Salehi, A., 2017. Microeconomic origins of macroeconomic tail risks. The American Economic Review, 107(1), 54-108. http://dx.doi.org/10.1257/aer.20151086

Ahn, H. J., Bae, K. H., and Chan, K., 2001. Limit orders, depth, and volatility: Evidence from the stock exchange of Hong Kong. The Journal of Finance, 56(2), 767-788. http://dx.doi.org/10.1111/00221082.00345

Al-Awadhi, A. M., Alsaifi, K., Al-Awadhi, A., and Alhammadi, S., 2020. Death and contagious infectious diseases: Impact of the COVID-19 virus on stock market returns. Journal of Behavioral and Experimental Finance, 27, 100326. http://dx.doi.org/10.1016/j.jbef.2020.100326

Amihud, Y., 2002. Illiquidity and stock returns: Cross-section and time-series effects. Journal of Financial Markets, 5(1), 31-56. http://dx.doi.org/10.1016/S1386-4181(01)00024-6

Amihud, Y., and Mendelson, H., 1986. Liquidity and stock returns. Financial Analysts Journal, 42(3), 43-48. http://dx.doi.org/10.2469/faj.v42.n3.43 
Bai, J., Krishnamurthy, A., and Weymuller, C. H., 2018. Measuring liquidity mismatch in the banking sector. The Journal of Finance, 73(1), 51-93. http://dx.doi.org/10.1111/jofi.12591

Baig, A. S., Butt, H. A., Haroon, O., and Rizvi, S. A. R., 2021. Deaths, panic, lockdowns and US equity markets: The case of COVID-19 pandemic. Finance Research Letters, 38, 101701. http://dx.doi.org/10.1016/j.frl.2020.101701

Bekaert, G., and Harvey, C. R., 2017. Emerging equity markets in a globalizing world. SSRN, 2344817. https://papers.ssrn.com/sol3/papers.cfm?abstract_id=2344817. http://dx.doi.org/10.2139/ssrn.2344817

Berkman, H., and Nguyen, N. H., 2010. Domestic liquidity and cross-listing in the United States. $\begin{array}{lllll}\text { Journal of Banking \& Finance, 34(6), } & 1139-1151 .\end{array}$ http://dx.doi.org/10.1016/j.jbankfin.2009.11.011

Bloom, N., 2009. The impact of uncertainty shocks. Econometrica, 77(3), 623-685. http://dx.doi.org/10.3982/ECTA6248

Brockman, P., and Chung, D. Y., 1999. Bid-ask spread components in an order-driven environment. Journal of Financial Research, 22(2), 227-246. http://dx.doi.org/10.1111/j.14756803.1999.tb00724.x

Brunnermeier, M. K., and Pedersen, L. H., 2009. Market liquidity and funding liquidity. Review of Financial Studies, 22(6), 2201-2238. http://dx.doi.org/10.1093/rfs/hhn098

Capponi, F., Cont, R., and Sani, A., 2019. Trade duration, volatility and market impact. Volatility and Market. Volatility and Market. http://dx.doi.org/10.2139/ssrn.3351736

Cecchetti, S. G., and Disyatat, P., 2010. Central bank tools and liquidity shortages: Federal Reserve Bank of New York.

Cheng, J., Powell, T., Skidmore, D., and Wessel, D., 2020. What's the Fed doing in response to the COVID-19 crisis? What more could it do? , from https://www.brookings.edu/research/fedresponse-to-covid19/

Chiu, J., Chung, H., Ho, K. Y., and Wang, G. H., 2012. Funding liquidity and equity liquidity in the subprime crisis period: Evidence from the ETF market. Journal of Banking \& Finance, 36(9), 2660-2671. http://dx.doi.org/10.1016/j.jbankfin.2012.06.003

Diamond, D. W., and Rajan, R. G., 2001. Liquidity risk, liquidity creation, and financial fragility: A theory of banking. Journal of Political Economy, 109(2), 287-327. http://dx.doi.org/10.1086/319552

Ding, W., Levine, R., Lin, C., and Xie, W., 2020. Corporate immunity to the COVID-19 pandemic National Bureau of Economic Research, w27055.

Ederington, L. H., and Lee, J. H., 1996. The creation and resolution of market uncertainty: The impact of information releases on implied volatility. Journal of Financial and Quantitative Analysis, 31(4), 513-539. http://dx.doi.org/10.2307/2331358

Giroud, X., and Mueller, H. M., 2017. Firm leverage, consumer demand, and employment losses during the Great Recession. The Quarterly Journal of Economics, 132(1), 271-316. http://dx.doi.org/10.1093/qje/qjw035

Glosten, L. R., and Milgrom, P. R., 1985. Bid, ask and transaction prices in a specialist market with heterogeneously informed traders. Journal of Financial Economics, 14(1), 71-100. http://dx.doi.org/10.1016/0304-405X(85)90044-3

Hasbrouck, J., 1988. Trades, quotes, inventories, and information. Journal of Financial Economics, 22(2), 229-252. http://dx.doi.org/10.1016/0304-405X(88)90070-0

Ibikunle, G., and Rzayev, K., 2020. Volatility, dark trading and market quality: evidence from the 2020 COVID-19 pandemic-driven market volatility. SSRN. http://dx.doi.org/10.2139/ssrn.3586410

International Monetary Fund, 2020a. COVID-19 Crisis Poses Threat to Financial Stability. from https://blogs.imf.org/2020/04/14/covid-19-crisis-poses-threat-to-financial-stability/

International Monetary Fund, 2020b. Policy Response to COVID-19. from https://www.imf.org/en/Topics/imf-and-covid19/Policy-Responses-to-COVID-19\#S 
Kahle, K. M., and Stulz, R. M., 2013. Access to capital, investment, and the financial crisis. Journal of Financial Economics, 110(2), 280-299. http://dx.doi.org/10.1016/j.jfineco.2013.02.014

Kang, W., and Zhang, H., 2014. Measuring liquidity in emerging markets. Pacific-Basin Finance Journal, 27, 49-71. http://dx.doi.org/10.1016/j.pacfin.2014.02.001

Long, J. B., and Plosser, C. I., 1983. Real business cycles. Journal of Political Economy, 91(1), 39-69. http://dx.doi.org/10.1086/261128

Lou, X., and Shu, T., 2017. Price impact or trading volume: Why is the Amihud (2002) measure priced? Review of Financial Studies, 30(12), 4481-4520. http://dx.doi.org/10.1093/rfs/hhx072

Marozva, G., 2020. Stock Market Liquidity and Monetary Policy. International Journal of Economics \& Business Administration, 8(2), 265-275. http://dx.doi.org/10.35808/ijeba/459

Marozva, G., and Makina, D., 2020. Liquidity risk and asset liability mismatches: Evidence from South $\begin{array}{llll}\text { Africa. Studies in Economics and Econometrics, 44(1), 73-112. } & \text {. }\end{array}$ http://dx.doi.org/10.1080/10800379.2020.12097357

Pastor, L., and Veronesi, P., 2012. Uncertainty about government policy and stock prices. The Journal of Finance, 67(4), 1219-1264. http://dx.doi.org/10.1111/j.1540-6261.2012.01746.x

Pinkowitz, L., Stulz, R. M., and Williamson, R., 2016. Do US firms hold more cash than foreign firms do? Review of Financial Studies, 29(2), 309-348. http://dx.doi.org/10.1093/rfs/hhv064

Reinhart, C. M., and Rogoff, K. S., 2009. This time is different: Eight centuries of financial folly: Princeton University Press.

Stoll, H. R., 2000. Presidential address: Friction. The Journal of Finance, 55(4), 1479-1514. http://dx.doi.org/10.1111/0022-1082.00259

Tetlock, P. C., 2007. Giving Content to Investor Sentiment: The Role of Media in the Stock Market. The Journal of Finance, 62(3), 1139-1168. http://dx.doi.org/10.1111/j.1540-6261.2007.01232.x

World Health Organisation, 2020. New WHO estimates: Up to 190000 people could die of COVID-19 in Africa if not controlled from https://www.afro.who.int/news/new-who-estimates-190-000people-could-die-covid-19-africa-if-not-controlled

Zhang, D., Hu, M., and Ji, Q., 2020. Financial markets under the global pandemic of COVID-19. Finance Research Letters, 36, 101528. http://dx.doi.org/10.1016/j.frl.2020.101528

Zhu, H., 2014. Do dark pools harm price discovery? The Review of Financial Studies, 27, 747-789.

\section{Copyright}

() () $($ This article is an open access article distributed under the terms and conditions of the c) Creative Commons Attribution-NonCommercial-NoDerivatives 4.0 International License. 